\title{
Analisa Kemampuan Mengontrol Marah ditinjau dari Penerapan REBT (Rational Emotive Behaviour Theraphy) pada Klien Skizofrenia di UPT Bina Laras Kras Kediri
}

\author{
Lingga Kusuma Wardani ${ }^{1}$, Dhita Kurnia Sari ${ }^{1}$ \\ ${ }^{1}$ STIKes Surya Mitra Husada Kediri \\ Email: linggakusumawardani@gmail.com \\ Received $x$ August 2018; Accepted x August 2018; Published 6 November 2018
}

\begin{abstract}
One of schizophrenia symptoms is tantrum; to hurt people and environment, it is done to express resentment or anger which is not constructive. Anger is an aggravation which emerges as a response to anxiety or unfulfilled need and perceived as a threat. This research aims to analyze the relation between REBT (Rational Emotive Behaviour Therapy) and the ability to control anger to schizophrenics in UPT Bina Laras Kras Kediri. Research design uses observational analytic with crossectional approach. The population is all schizophrenics in UPT Bina Laras Kras Kediri, the sampling technique used is purposive sampling by getting 13 respondents, the data collection used are REBT questionnaire and observation sheet of the ability to control anger. Data analysis uses ordinal regression with $\mathrm{p}$ value $0,001<\mathrm{a} 0,05$ means there is REBT application and the ability to control anger to schizophrenia patients in UPT Bina Laras Kras Kediri. The research results from 13 respondents are 9 respondents can apply REBT, and 9 respondents can control their anger. The ability to manage good emotion in dealing with other people, to recognize their and others' feeling, and to motivate themselves can be formed by applying rational emotive behaviour theraphy sustainably.
\end{abstract}

Keywords: The ability to control anger, REBT

Copyright $\left({ }^{\circ} 2018\right.$ STIKes Surya Mitra Husada

All right reserved.

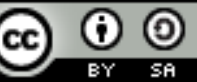

This is an open-acces article distributed under the terms of the Creative Commons AttributionShareAlike 4.0 International License.

\section{PENDAHULUAN}

Penderita Skizofrenia mendominasi jumlah penderita gangguan jiwa, yaitu 99\% dari seluruh gangguan jiwa di rumah sakit jiwa. Prevalensi penderita skizofrenia di Indonesia adalah 0,3-1 \% dan dapat timbul pada usia 18-45 tahun, bahkan ada yang timbul pada penderita usia 11-12 tahun. Apabila penduduk Indonesia berjumlah 200 juta jiwa, maka diperkirakan sekitar 2 juta jiwa penduduk menderita skizofrenia. Perilaku kekerasan merupakan salah satu tanda dan gejala dari gangguan jiwa. WHO (2001) menyatakan, paling tidak ada satu dari empat orang di dunia mengalami masalah mental. WHO memperkirakan ada sekitar 450 juta orang di dunia mengalami gangguan kesehatan jiwa. Pada masyarakat umum terdapat $0,2-0,8 \%$ penderita skizofrenia dan dari 120 juta penduduk di Negara Indonesia terdapat kira-kira 2.400 .000 orang anak yang mengalami gangguan jiwa (Maramis, 
2004). Berdasarkan studi pendahuluan di UPT Bina Laras Kras Kediri Bulan Juli 2018 didapatkan data terdapat 112 penghuni dan 20 diantaranya penderita skizofrenia post MRS dari Rumah Sakit Jiwa yang menunjukkan tanda gejala perilaku kekerasan dan resiko perilaku kekerasan. UPT Bina Laras Kras merupakan lembaga sosial milik Dinas Sosial Pemerintah Jawa Timur yang berfungsi sebagai tempat untuk merawat klien gangguan jiwa setelah dirawat dari Rumah Sakit Jiwa, dalam arti disini UPT sebagai tempat rehabilitasi bagi klien gangguan jiwa post MRS yang tidak memiliki keluarga dan atau memiliki keluarga tetapi keluarga belum siap menerima penderita gangguan jiwa kembali ke rumah, sehingga untuk sementara waktu dititipkan di UPT Bina Laras Kras Kediri. tidak memiliki banyak perawat yang memiliki keahlian untuk merawat klien skizofrenia salah satunya perilaku kekerasan. Terapi yang diberikan selama ini hanya berupa pendampingan dan terapi aktivitas kelompok (TAK) secara umum bukan per kasus atau per diagnosa keperawatan jiwa. Terapi REBT (Rational emotive behaviout theraphy) sudah diberikan dan diajarkan pada perawat yang ada di UPT secara berkelanjutan. Putri (2010) dalam penelitiannya terhadap 28 klien skizofrenia yang mengalami perilaku kekerasan menyatakan bahwa terapi Rational Emotive Behaviour Therapy (REBT) mampu meningkatkan kemampuan kognitif sebesar 9.6\% dan sosial 47\%. REBT juga mampu menurunkan respon emosi $43 \%$, fisiologis $76 \%$, dan perilaku $47 \%$. Penurunan gejala perilaku kekerasan masih bisa dioptimalkan jika dipadukan dengan tindakan keperawatan spesialis. Perilaku kekerasan pada kelompok yang mendapatkan terapi generalis dan assertive training menurun secara bermakna pada respon fisik, respon kognitif, respon perilaku dan respon sosial klien. Terapi perilaku kognitif dapat meningkatkan kemampuan kognitif dan perilaku klien gangguan jiwa yang mengalami perilaku kekerasan. Respon kognitif merupakan hasil penilaian terhadap kejadian yang menekan, pilihan koping yang digunakan, reaksi emosional, fisiologis, perilaku dan sosial individu (Stuart \& Laraia, 2005). Berdasarkan teori diatas maka perlu adanya tindakan keperawatan pada klien dengan perilaku kekerasan yang mengarah pada fisik, afektif, emosi, sosial, kognitif dan perilakunya.

\section{METODE}

Rancangan penelitian yang dipakai adalah korelasional dengan pendekatan crossectional. Populasi adalah semua klien skizofrenia di UPT Bina Laras Kras, teknik sampling dengan menggunakan purposive sampling didapatkan 13 yang memenuhi kriteria inklusi penelitian. pengumpulan data dengan observasi kemampuan mengendalikan emosi. Instrumen yang digunakan dalam penelitian ini adalah lembar observasi, dimana digunakan untuk mengukur Kemampuan mengendalikan emosi marah pada klien perilaku kekerasan di UPT Bina Laras Kras Kabupaten Kediri. Petugas pengumpulan data adalah peneliti. Untuk menjaga kualitas data, peneliti memimpin secara langsung sejak tahap persiapan sampai akhir analisis data dengan melakukan rangkaian kegiatan yaitu : menyusun lembar kuesioner penerapan REBT dan lembar observasi kemampuan mengendalikan marah. Analisa data dengan uji ordinal regression dengan p value $0,000<\alpha 0,05$ $(5 \%)$.

\section{HASIL}

\section{A. Identifikasi Variabel}

1. Penerapan REBT (rational emotive behaviour theraphy) pada klien skizofrenia di UPT Bina Laras Kras Kediri

Tabel 4.1 penerapan REBT (Rational Emotive behaviour Theraphy) pada bulan Juli 2018 di UPT Bina Laras Kras Kabupaten kediri

\begin{tabular}{clccc}
\hline No. & penerapan & Frekuensi & $\%$ \\
\hline 1. & Mampu & 9 & 69.2 \\
\hline 2. & Tidak mampu & 4 & 30.8 \\
\hline & & Total & 13 & 100.0 \\
\hline
\end{tabular}


2. Kemampuan mengontrol marah pada klien skizofrenia di UPT Bina Laras Kras Kediri

Tabel 4.2 kemampuan mengontrol marah klien skizofrenia pada bulan Juli 2018 di UPT Bina Laras Kras Kabupaten Kediri

\begin{tabular}{clccc}
\hline No. & Kemampuan mengontrol marah & Frekuensi & $\%$ \\
\hline 1. & Mampu & 9 & 69.2 \\
\hline 2. & Tidak mampu & & 4 & 30.8 \\
\hline & & Total & 13 & 100.0 \\
\hline
\end{tabular}

Dari tabel 4.1 didapatkan dari 13 responden mampu mengendalikan emosi (100\%) sesudah pemberian REBT ( Rational Emotive Behaviour)

\section{B. Tabulasi Silang Antar Variabel}

Tabel 4.3 Tabulasi silang Analisa penerapan REBT (Rational emotive Behaviour theraphy) terhadap kemampuan mengontrol marah pada klien skizofrenia pada bulan Juli 2018 di UPT Bina Laras Kras Kabupaten Kediri

\begin{tabular}{cccc}
\hline Penerapan REBT & \multicolumn{2}{c}{ Kemampuan mengontrol marah } & Total \\
\hline & mampu & Tidak mampu & \\
\hline mampu & 9 & 4 & \\
\hline tidak mampu & 9 & 4 & 13 \\
\hline
\end{tabular}

\section{Analisa Data}

Tabel 4.4 kemampuan mengontrol marah ditinjau dari penerapan REBT klien skizofrenia pada bulan Juli 2018 di UPT Bina Laras Kras Kabupaten kediri

\begin{tabular}{cc}
\hline Hasil uji statistik & \\
\hline $\mathrm{N}$ & 13 \\
\cline { 2 - 2 } Exact signifikasi (2-tailed) & 0.000 \\
\hline
\end{tabular}

Dari hasil uji statistik ordinal regression didapatkan p value $0.000<\alpha(0,05)$ artinya jika klien skizofrenia memiliki kemampuan menerapkan REBT (Rational emotive behavior theraphy) maka klien akan mampu mengontrol marah klien skizofrenia di UPT Bina Laras Kediri.

\section{PEMBAHASAN}

A. Penerapan REBT (Rational emotive behaviour theraphy) di UPT Bina Laras Kras Kabupaten Kediri

Dari hasil penelitian didapatkan 9 (69.2\%) responden mampu melakukan REBT (rational emotive behavour theraphy) dengan perilaku kekerasan dari 13 responden.

Pemberian rational emotive behaviour theraphy mampu meningkatkan kemampuan kognitif yaitu hasil dari penilaian individu terhadap kejadian yang menekan pilihan koping yang digunakan reaksi emosional, fisiologis, perilaku dan sosial individu (Stuart \& Laraia, 2005).

Rational Emotive Behaviour Therapy (REBT) merupakan salah satu psikoterapi yang dapat diberikan pada klien dengan perilaku kekerasan dengan tujuan umumnya adalah untuk mengurangi keyakinan irrasional dan menguatkan keyakinan rasional yang dapat efektif pada anak dan dewasa yang marah dan agresif melalui pembelajaran dan latihan kognitif, emosi dan perilaku. Dengan demikian diharapkan klien dengan perilaku kekerasan yang mempunyai keyakinan dan pikiran yang irrasional sehingga akan memiliki emosi dan perilaku yang positif dan lebih sehat. 
Bentuk emosi salah satunya adalah reaksi amarah atau marah. Sumber utama dari kemarahan adalah hal-hal yang mengganggu aktivitas untuk sampai pada tujuanya dan untuk menyalurkan ketegangan individu yang bersangkutan menjadi marah, ketika marah menyebabkan gelombang energi yang cukup kuat untuk bertindak dahsyat maka tangan menjadi mudah menghantam lawan, kesal, mengamuk, bermusuhan. Reaksi berikutnya takut, dimana pasien mengalami perasaan yang mendorong untuk menjauhi dan menghindar dengan hal yang membuat dirinya takut. Reaksi juga bisa berupa perasaan sedih, khawatir. Pasien dengan perilaku kekerasan mengalami kesulitan dalam mengendalikan emosi, sehingga sulit untuk mengenal dan menyampaikan perasaan yang dialami, mengidentifikasi kejadian yang dialami apakah klien bisa memahami peristiwa yang terjadi, dengan identifikasi masalah yang bisa diselesaikan dengan baik. Pada saat sesuatu yang menyebabkan marah itu tidak dapat diidentifikasi dengan baik, dan menekan perasaan, sehingga cenderung menjadi marah dan terdorong dan menjadi agresif jika harus jika harus menghadapi keadaan yang mengganggunya maka sangatlah mudah bagi seseorang untuk mengungkapkan emosi yang negatif dengan bentuk amarah atau rasa marah. Pada klien skizofrenia dengan respon emosi marah selama mereka mampu melakukan REBT klien mampu mengubah keyakinan irrasionalnya menjadi rasional melalui latihan terhadap kognitif, emosi dan perilaku, klien juga mampu memahami rentang perasaan marahnya yang dirasakan.

\section{B. Kemampuan mengontrol marah klien skizofrenia di UPT Bina Laras Kediri}

Dari hasil penelitian didapatkan 9 responden (69.2\%) mampu mengontrol marah. Perilaku kekerasan merupakan salah satu respon maladaptive dari rasa marah. Marah adalah reaksi emosional akut yang ditimbulkan oleh sejumlah situasi yang merangsang, termasuk ancaman, agresi lahiriah, pengekangan diri, serangan lisan, kekecewaan atau frustasi (Triantoro, 2002).

Menurut Yosep, (2011) mengemukakan bahwa tanda dan gejala perilaku kekerasan adalah sebagai berikut: fisik ( muka merah, tegang, mata melotot, tangan mengepal, mondar- mandir), verbal (bicara kasar, suara tinggi, membentak, mengancam, mengumpat kata-kata kotor), perilaku (melempar, memukul, menyerang orang, melukai diri sendiri, orang lain, amuk agresif), emosi (tidak adekuat, tidak nyaman, rasa terganggu, jengkel, tidak berdaya, bermusuhan, mengamuk, ingin berkelahi, menyalahkan, menuntut). Kemampuan mengontrol marah responden yaitu perilaku untuk memahami dan mengatasi masalah emosi dan perilaku negatif yang berasal dari keyakinan-keyakinan yang tidak rasional (irrasional), mereka dapat memahami rentang perasaan marahnya, mampu berfikir rasional berbicara deng' 'pjan baik dan jelas, tidak merasa tersinggung dan bersalah apabila di tolak, saat berbicara intonasi suara tidak mengancam, dapat berinteraksi dengan baik dan menghargai orang lain. sehingga memungkinkan klien untuk melakukan koping yag efektif dalam jangka waktu yang panjang.

C. Analisa penerapan REBT (Rational emotive behaviour theraphy) terhadap kemampuan mengontrol marah klien skizofrenia di UPT Bina Laras Kras Kediri

Dari hasil uji statistik dengan Chi square didapatkan nilai signifikansi atau p value $0,000<\alpha$ 0,05 yang artinya terdapat hubungan penerapan REBT (rational emotive behavior theraphy) dengan kemampuan mengontrol marah klien skizofrenia di UPT Bina Laras Kras Kediri.

Putri (2010) dalam penelitiannya terhadap 28 klien skizofrenia yang mengalami perilaku kekerasan menyatakan bahwa terapi Rational Emotive Behaviour Therapy (REBT) mampu meningkatkan kemampuan kognitif sebesar 9.6\% dan sosial 47\%. REBT juga mampu menurunkan respon emosi $43 \%$, fisiologis $76 \%$, dan perilaku $47 \%$.REBT merupakan salah satu psikoterapi yang dapat diberikan pada klien dengan perilaku kekerasan dengan tujuan umumnya unuk mengurangi keyakinan irrasional dan menguatkan keyakinan rasioanal yang dapat efektif pada anak dan dewasa yang marah dan agresif melalui pembelajaran dan latihan kognitif, emosi dan perilaku.(Keliat B.A,2012).

Responden dengan perilaku kekerasan banyak mengalami kesulitan dalam menyelesaikan masalah,sehingga cara mengatasi masalah dngan cara yang maladaptif. Respon marah bisa mencakup kognitif klien misalnya yang normalnya bisa berfikirBanyak kladap suatu peristiwa atau kejadian menjadi berfikir yang irrasional karena memiliki tujuan yang tidak realistis.kurang percaya diri, 
cenderung menyalahkan orang lain dan mengkritik tingkah laku orang lain. Sehingga responden dengan perilaku kekerasan mengalami kesulitan dalam mengidentifikasi perasaan, kebutuhan dan keinginanya untuk diungkapkan kepada orang lain.

Dengan dilakukanya REBT bisa meningkatkan kemampuan mengontrol marah yang baik bagi responden dengan perilaku kekerasan yang sebelumnya tidak dapat mengendalikan emosi marahnya menjadi mampu berfikir yang rasional, mampu memhami rentang dari perasaan senang sampai marah yang dirasakanya. Mampu membedakan antara kenyataan dengan persepsi terhadap suatu kondisi atau peristiwa, sehingga memungkinkan responden dapat melakukan koping yang adaptif terhadp suatu peristiwa dlam jangka waktu lama. REBT mampu meningkatkan kemampuan kognitif responden perilaku kekerasan.

\section{KESIMPULAN}

1. Penerapan REBT (rational emotive behaviour theraphy) pada klien skizofrenia di UPT Bina Laras Kras Kediri semua responden mampu melakukan REBT sebesar 9 responden (69.2\%)

2. Kemampuan mengontrol marah klien skizofrenia semua responden mampu mengontrol marah sebesar 9 responden $(69.2 \%)$

3. Kemampuan klien skizofrenia melakukan REBT (Rational emotive behavior theraphy) mempengaruhi kemampuan dalam mengontrol marah

\section{REFERENSI}

APA. (2004). Diagnostic and Statistic Manual of Mental Disorder IV-ER Ed 4. Arlington VA: American Psychiatric Association.

Banks, T., \& Ziots, P. (2009). Teaching a Cognitive Behavioral Strategy to Manage Emotions Rationale Emotive Behaviour Theraphy in an Educational Setting. http://isc.sagepub.com. Diakses tanggal 09 April 2016.

Corey. (2009). Theory and Practice of Counseling and Psychotherapy. Belmont, CA: Brooks/Cole.

Frogrratt, W. (2006). Free From Stress: Panduan untuk Mengatasi Cemas. Bhuana Ilmu Populer. Jakarta.

Jensen. (2008). Evaluating the ABC Models of Rationale Emotive Behaviour Theraphy Theory: an analysis of the relationship between irrational thinking and guilt. Thesis of science of Pchycology. The Faculty of Departement Psychology Villanova University. United State. Proquest LLC.

Keliat, B. A. (2012). Model Praktik Keperawatan Profesional Jiwa. Jakarta: EGC.

Kusumawati, F. \& Hartono, Y. (2011). Buku Ajar Keperawatan Jiwa. Jakarta: Salemba Medika.

Maramis, W. (2004). Catatan Ilmu Kedokteran Jiwa Cetakan 8. Surabaya: Airlangga University Press.

Nursalam. (2013). Konsep dan Penerapan Metodologi Penelitian Ilmu Keperawatan. Jakarta: Salemba Medika.

Putri. (2010). Pengaruh rational emotive behaviour therapy pada klien dengan perilaku kekerasan di Rumah Sakit Marzoeki Mahdi Bogor.Tesis. Tidak dipublikasikan.

Stuart, G. W., \& Laraia, M. T. (2005). Principles and Practice of Psychiatric Nursing. (7th Edition). St. Louis: Mosby.

Triantoro, S. (2005). Terapi \& Konseling Gestalt. Yogyakarta: Graha Ilmu

Varcarolis, E. (2000). Psychiatric Nursing Clinical Guide: Assesment Tools \& Diagnosis. Philadelphia: W. B. Saunders Company.

Yosep, I. (2011). Keperawatan Jiwa. (Edisi revisi). Bandung. Refika Aditama. 